\title{
FORMULASI ORGANISASI DALAM PERSPEKTIF AL-QUR'AN DAN AL-HADITS
}

\author{
Oleh. \\ Ghufron Jayadi \\ STAI Cendekia Insani Situbondo \\ ghufronjayadi92@gmail.com
}

\begin{abstract}
:
Term organization has two general sense. First organization is defined as an institution or a functional group and Second is organization itself defined as a collection of people with a system of cooperation to achieve common goals. There are two auxiliary words contained in Qur'an to learn about this organization. The word is Shaff and the ummah. To said Shaff inspire to concept that organization must have a member that consists of a collection of people, are in a container, there is regularity, has a goal, also had leaders, occurred delegation of authority and responsibility and no intention of carrying out the task with sincerity and fighting in the street God. In order to realize a good organization, effectively, efficiently and in accordance with the needs, selectively must be based on principles of organization are grounded in the teachings of Islam.
\end{abstract}

Key Words: Organization, Perspective, the Qur'an and the Hadith

\section{A. Pendahuluan}

Kata manajemen berasal dari bahasa Prancis kuno ménagement, yang memiliki arti seni melaksanakan dan mengatur. Manajemen belum memiliki definisi yang mapan dan diterima secara universal. Mary Parker Follet, misalnya, mendefinisikan manajemen sebagai seni menyelesaikan pekerjaan melalui orang lain. Definisi ini berarti bahwa seorang manajer bertugas mengatur dan mengarahkan orang lain untuk mencapai tujuan organisasi.Ricky W. Griffin mendefinisikan manajemen sebagai sebuah proses perencanaan, pengorganisasian, pengkoordinasian, dan pengontrolan sumber daya untuk mencapai sasaran (goals) secara efektif dan efesien. ${ }^{1}$ Efektif berarti bahwa tujuan dapat dicapai sesuai dengan perencanaan, sementara efisien berarti bahwa tugas yang ada dilaksanakan secara benar, terorganisir, dan sesuai dengan jadwal.

1Wikipedia bahasa Indonesia, Ensiklopedia Bebas, Manajemen, diakses dari http://www.ririsatria.net/category/manajemen-organisasi, tanggal 25 Januari 2013

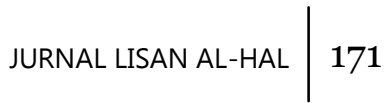


Sebagaimana diterangkan bahwa salah satu aspek terpenting dari sebuah manajemen adalah adanya pengorganisasian. Pengorganisasian yang baik haruslah mempunyai pijakan yang baik dan etika dalam berorganisasi. Pengorganisasian yang baik akan menghasilkan organisasi yang baik, mulai dari strukturnya, sumber daya manusianya, maupun aspek yang lainnya.

Pendidikan Islam akan dapat berhasil dan berjalan dengan efektif dan efisien apabila ditopang dengan adanya organisasi yang kokoh dan baik. Namun sebaliknya, apabila organisasinya lemah dan keropos, maka pendidikan akan berjalan ibarat pepatah hidup segan matipun tak mau. Sehingga dapat dikatakan pengorganisasian juga merupakan awal mula kesuksesan suatu lembaga atau instansi pendidikan Islam. Maka dari itu, diperlukan pengorganisasian yang teori serta etikanya diambil dari alQur'an dan hadits.

Berpijak dari hal itu, untuk menjelaskan lebih lanjut mengenai halhal yang berkaitan dengan pengorganisasian dalam perspektif al-Qur'an dan hadits, penulis akan menyusun sebuah makalah yang berjudul "Pengorganisasian dalam Perspektif al-Qur'an dan hadits" yang penulis kumpulkan dari berbagai referensi yang ada

\section{A. Pengertian Organiasi}

\section{Menurut Al-Quran}

Terdapat dua kata bantu yang terdapat dalam al-Qur'an untuk mempelajari pengorganisasian ini. Kata tersebut adalah Shaff dan ummat. Penulis akan membahas dua kata tersebut satu per satu.

Penulis mengidentikkan kata shaff ini dengan organisasi. Jadi organisasi menurut analisis kata ini adalah suatu perkumpulan atau jamaah yang mempunyai sistem yang teratur dan tertib untuk mencapai tujuan bersama. Dalam surah al-Shaff ayat 4 dikemukakan:

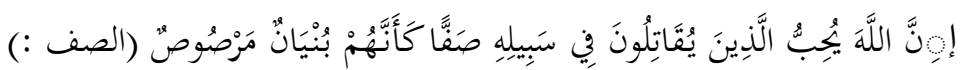

"Sesungguhnya Allah menyukai orang yang berperang dijalan-Nya dalam barisan yang teratur seakan-akan mereka seperti suatu bangunan yang tersusun kokoh"

Maksud dari shaff disitu menurut al-Qurtubi adalah menyuruh masuk dalam sebuah barisan (organisasi) supaya terdapat keteraturan untuk mencapai tujuan. ${ }^{2}$ Dalam sebuah hadits diterangkan:

2Samsyu al-Din al-Qurtubi, Jami' al-Bayan li al-Ahkam al-Qur'an, juz 1, (Mauqi'u alTafasir: Dalam Software Maktabah Samilah, 2005), hlm. 5594.

$172 \mid$ JURNAL LISAN AL-HAL 


$$
\text { إن الله عز وجل يحب إذا عمل أحدكم عملا أن يتقنه }
$$

"Sesungguhnya Allah mencintai orang yang jika melakukan suatu pekerjaan dilakukan dengan "tepat, terarah dan tuntas".3

Suatu pekerjaan apabila dilakukan dengan teratur dan terarah, maka hasilnya juga akan baik. Maka dalam suatu organisasi yang baik, proses juga dilakukan secara terarah dan teratur atau itqan.

Menurut al-Baghawi maksud dari ayat di atas adalah manusia seyogyanya tetap pada tempatnya dan tidak bergoyah dari tempat tersebut.4 Di samping itu, dalam ayat tersebut banyak mufassir yang menerangkan bahwa ayat tersebut adalah barisan dalam perang. ${ }^{5}$ Maka ayat tersebut mengindikasikan adanya tujuan dari barisan perang yaitu berupaya untuk melaksanakan kewajiban yaitu jihad di jalan allah dan memperoleh kemenangan.

Dalam penafsiran versi lain, dikemukakan bahwa ayat tersebut menunjukkan barisan dalam shalat yang memiliki keteraturan. ${ }^{6}$ Dari sini dapat dikemukakan bahwa ciri organisasi adalah mempunyai pemimpin dan terjadi itba' terhadap kepemimpinan tersebut. Di samping itu, kata bunyanun marshusun mengindikasikan bahwa dalam sebuah organisasi hendaknya terdapat pembagian wewenang dan tugas, sebagaimana yang terjadi dalam sebuah bangunan atau rumah, ada yang bertugas menjadi tangga, ada yang bertugas menjadi tiang, serta ada yang bertugas menjadi atap dan sebagainya. Dalam sebuah hadits diterangkan:

$$
\text { إِنَّ اللَّةَ كَتَبَ الْإِحْسَانَ عَلَى كُكَّ شَيْء....... }
$$

"Sesungguhnya Allah mewajibkan (kepada kita) untuk berbuat yang optimal dalam segala sesuatu...".7

Dalam menerima delegasi wewenang dan tanggung jawab hendaknya dilakukan dengan optimal dan sungguh-sungguh. Janganlah anggota suatu organisasi melakukan tugas dan wewenangnya dengan asalasalan. Dalam sebuah hadits diterangkan bahwa apabila seseorang hanya

3 Al-Thabrani, Mu'jam al-Ausath, juz 2, (Mauqi'u al-Islam: Dalam Software Maktabah Syamilah, 2005), 408.

${ }^{4}$ Abu Muhammad Hasan ibn Mas'ud al-Baghawi, Mu'alim al Tanzil juz 8, (Dar Tayyibah lin Nasr: Dalam Software Maktabah Samilah, 2005), hlm. 108.

5 Ibn Jarir al-Thabari, Tafsir Jami' al Bayan fi ta'wil al-Qur'an, juz 23, (Mauqiu Majma' al Mulk: dalam Software Maktabah Samilah, 2005), hlm. 357.

6al-Qurtubi, Jami' al-Bayan li al-Ahkam al-Qur'an, juz 1..., hlm. 5594.

${ }^{7}$ Muslim al-Hajaj, Shahih Muslim, juz 10, (Mauqi'u al-Islam Dalam Software Maktabah Syamilah, 2005), 122, hadits No. Hlm. 3615. 
mementingkan kepentingan sepihak dan melakukan tugas serta tanggung jawabnya dengan asal-asalan. Hadits yang menerangkan tentang kekalahan umat Islam dalam perang Uhud menunjukkan bahwa apabila seseorang tidak melaksanakan anggotanya sebagai bagian dari organisasi perang, maka akibatnya adalah organisasi tersebut mengalami kekalahan. ${ }^{8}$ Jadi dalam sebuah organisasi harus terjadi koordinasi yang baik dan tidak boleh terjadi penyalahgunaan wewenang.Dalam ayat lain diterangkan:

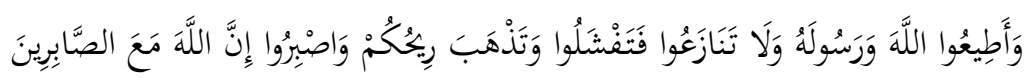

"Dan taatlah kepada Allah dan Rasul-Nya dan janganlah kamu berbantahbantahan, yang menyebabkan kamu menjadi gentar dan hilang kekuatanmu dan bersabarlah. Sesungguhnya Allah beserta orang-orang yang sabar". (Q.S. al-Anfal: 46)

Ayat tersebut menerangkan bahwa dalam sebuah organisasi tidak boleh terdapat percekcokan yang membawa kepada permusuhan yang pada akhirnya mengakibatkan hancurnya kesatuan. ${ }^{9}$ Dalam tafsirnya alMaraghi menerangkan pertentangan yang menyebabkan rusaknya koordinasi dan organisasi akan membawa kepada kelemahan dan kegagalan. ${ }^{10}$

Berorganisasi sangat penting dan merupakan hal yang pokok untuk menjalankan sebuah manajemen. Al-Qur'an menjelaskan:

........

"....Tegakkanlah agama dan janganlah kamu berpecah belah tentangnya..."(Q.S.Al-Syuura: 13)

Ayat di atas menjelaskan bahwa anggota organisasi dilarang keluar dari organisasi dan dilarang memecah belah organisasi.

Perkataan ( qawl) dari Sayyidina Ali bin Abi Thalib:

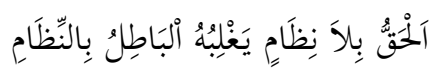

"Kebenaran yang tidak diorganisir dapat dikalahkan oleh kebatilan yang diorganisir."

Qawl ini mengingatkan kita tentang pentingnya berorganisasi dan sebaliknya bahayanya suatu kebenaran yang tidak diorganisir melalui

\footnotetext{
${ }^{8}$ Abu Abdillah Muhammad ibn Isma'il al Bukhari, Shahih Bukhari juz 12, (Mauqi'u al-Islam: dalam Software Maktabah Samilah, 2005), hlm. 437.

9 Jawahir Tanthowi, Unsur-Unsur Manajemen Menurut Ajaran Al-Qur'an, (Jakarta: Pustaka al-Husna, 1983), hlm. 72.

${ }^{10}$ Mustofa al-Maraghi, Tafsir al-Maraghi, (Kairo: Mustofa Babil Halabi, 1966), juz 4, hlm. 10 .
}

$174 \mid$ JURNAL LISAN AL-HAL 
langkah-langkah yang kongkrit dan strategi-strategi yang mantap. Maka tidak ada garansi bagi perkumpulan apa pun yang menggunakan identitas Islam meski memenangkan pertandingan, persaingan maupun perlawanan jika tidak dilakukan pengorganisasian yang kuat.

Di sini terdapat perbedaan yang mencolok antara organisasi umum dengan organisasi pendidikan Islam yang elemen-elemennya diambil dari al-Qur'an dan al-Hadits. Kata sabilihi dalam ayat surat al-Shaff di atas menunjukkan perbedaan bahwa orang yang menjadi anggota organisasi pendidikan Islam ada niat untuk berjuang karena Allah dalam melaksanakan tugas dan tanggung jawabnya

Berpijak dari keterangan dua mufassir di atas, maka dapat ditarik dalam teori manajemen bahwa organisasi mempunyai anggota yang terdiri dari kumpulan orang-orang, berada dalam suatu wadah, terdapat keteraturan, mempunyai tujuan, juga mempunyai pemimpin, terjadi pendelegasian wewenang dan tanggung jawab serta ada niat melaksanakan tugas dengan ikhlas dan berjuang di jalan Allah.

Hal tersebut nampaknya mempunyai kesamaan dan perbedaan dengan ciri serta elemen bahkan manfaat dan tujuan organisasi yang dikemukakan para ahli. Organisasi yang baik, menurut Purwanto, hendaklah memiliki ciri-ciri atau sifat sebagai berikut: a) Memiliki tujuan yang jelas, b) Tiap anggota dapat memahami dan menerima tujuan tersebut, c) Adanya kesatuan arah sehingga dapat menimbulkan kesatuan tindakan dan kesatuan pikiran, d) Adanya kesatuan perintah, e) Adanya keseimbangan antara wewenang dan tanggung jawab masing-masing anggota, f) Adanya pembagian tugas atau pekerjaan yang sesuai dengan kemampuan, keahlian dan bakat masing-masing, sehingga dapat menimbulkan kerjasama yang harmonis dan kooperatif, g) Pola organisasi hendaknya relatif permanen, dan struktur organisasi disusun sesederhana mungkin, sesuai dengan kebutuhan, koordinasi, pengawasan dan pengendalian, h) Adanya jaminan keamanan dalam bekerja, i) Adanya gaji atau insentif yang setimpal dengan jasa/pekerjaan sehingga dapat menimbulkan gairah kerja, dan j) Garis-garis kekuasaan dan tanggung jawab serta hierarkhi tata kerjanya jelas tergambar dalam struktur organisasi. ${ }^{11}$

\section{Menurut Al-Hadits}

Dalam bahasa Arab, pengorganisasian diistilahkan dengan altandhim. Menurut Mahmud Hawary:

${ }^{11}$ Purwanto, Administrasi dan Supervisi..., 17-18 


$$
\text { وضع كل شيء في مكانه وكل شخص في مكانه وربط الاشياء ببعضها والاشخاص ببعضها من اجل تكوين اكبر من بحرد الجمع الحسابي لآجزائها }
$$

"Menjalankan sesuatu sesuai dengan fungsinya, demikian juga setiap anggotanya dan merupakan ikatan dari perorangan terhadap yang lain, guna melakukan kesatuan tindakan yang tepat, menuju suksesnya fungsi masing-masing". ${ }^{2}$

Dari definisi di atas, penulis menyimpulkan bahwa organisasi adalah suatu wadah atau setiap bentuk perserikatan kerja sama manusia (didalamnya) ada struktur organisasi, pembagian tugas, hak dan tanggung jawab untuk mencapai tujuan bersama. Dari definisi tersebut, dapat diketahui bahwa pada intinya organisasi adalah wadah kerjasama manusia yang terstruktur untuk mencapai tujuan secara efektif dan efisien.

Jadi jika dua orang atau lebih berserikat atau bekerja sama untuk mengerjakan suatu pekerjaan yang mana bila mereka kerjakan sendirisendiri sulit untuk diselesaikan maka terjadilah suatu organisasi, minimal sederhana bentuknya. Semakin banyak jumlah orang yang tergabung dalam kerjasama tersebut, maka kerja sama harus semakin disempurnakan baik itu bentuknya (strukturnya), aturannya maupun aktivitasnya, karena hal itu menunjukkan bahwa organisasi tersebut semakin besar dan tentunya permasalahanpun akan semakin kompleks pula.

Dari pengertian organisasi di atas maka kita dapat menentukan beberapa unsur yang mana dengan unsur-unsur tersebut suatu organisasi akan terbentuk unsur-unsur itu antara lain :

1. Sekelompok Orang. Dimana dari orang-orang tersebut ada yang bertindak sebagai pemimpin dan bawahannya.

2. Kerjasama dengan orang yang berserikat. Dengan adanya kerja sama 'ntara orang orang yang berserikat tersebut, maka tentu ada pula, pembagian tugas (wewenang), tanggung jawab, hak dan kewajiban, struktur organisasi, aturan-aturan asas atau prinsif yang mengatur kerjasama tersebut.

3. Tujuan bersama hendak dicapai. Tujuan ini merupakan kesepakatan dari orang yang berserikat tersebut yang ahkirnya dikenal dengan istilah "tujuan organisasi."

Hal yang perlu diperhatikan dalam pengorganisasian adalah pembagian tugas, fungsi, wewenang dan tanggung jawab, hendaknya

${ }^{12}$ Sayyid Mahmud al-Hawary, Idarah al-Asas wa al-Ushul al-Ilmiyah, (Dar al-Kutub: Mesir, 1976), 189

176 JURNAL LISAN AL-HAL 
disesuaikan dengan pengalaman, bakat, minat, pengetahuan dan kepribadian masing-masing orang yang diperlukan dalam menjalankan tugas-tugas tersebut.

\section{Prinsip-prinsip Organisasi}

Agar terwujudnya suatu organisasi yang baik, efektif, efisien serta sesuai dengan kebutuhan, secara selektif harus didasarkan pada prinsipprinsip organisasi sebagai berikut:

a. Principle of Organizational Objective (prinsip tujuan organisasi). Menurut prinsip ini tujuan organisasi harus jelas dan rasional, apakah bertujuan untuk mendapatkan laba (business organization) ataukah untuk memberikan pelayanan (public organization). Hal ini merupakan bagian penting dalam menentukan struktur organisasi.

b. Principle of Unity of Objective (prinsip kesatuan tujuan). Menurut prinsip ini, di dalam suatu organisasi harus ada kesatuan tujuan yang ingin dicapai. Organisasi secara keseluruhan dan tiap-tiap bagiannya harus berusaha untuk mencapai tujuan tersebut. Organisasi akan kacau, jika tidak ada kesatuan.

c. Principle of Unity of Command (prinsip kesatuan perintah) Menurut prinsip ini, hendaknya setiap bawahan menerima perintah ataupun memberikan pertanggungjawaban hanya kepada satu orang atasan, tetapi seorang atasan dapat memerintah beberapa orang bawahan.

d. Principle of the Span of Management (prinsip rentang kendali). Menurut prinsip ini, seorang manajer hanya dapat memimpin secara efektif sejumlah bawahan tertentu, misalnya 3 sampai 9 orang. Jumlah bawahan ini tergantung kecakapan dan kemampuan manajer bersangkutan.

e. Principle of Delegation of Authority (prinsip pendelegasian wewenang) Menurut prinsip ini, hendaknya pendelegasian wewenang dari seseorang atau sekelompok orang kepada orang lain jelas dan efektif, sehingga ia mengetahui wewenangnya.

f. Principle of Parity of Authority and Responsibility (prinsip keseimbangan wewenang dan tanggung jawab) Menurut prinsip ini, hendaknya wewenang dan tanggung jawab harus seimbang. Wewenang yang didelegasikan dengan tanggung jawab yang timbul karenanya harus samabesarnya, hendaknya wewenang yang didelegasikan tidak meminta pertanggungja wabany ang lebih besar dari wewenang itu sendiri atau sebaliknya. Misalnya, jika wewenang sebesar X, tanggung jawabnya pun harus sebesar X pula. 
g. Principle of Responsibility (prinsip tanggung jawab). Menurut prinsip ini, hendaknya pertanggungjawaban dari bawahan terhadap atasan harus sesuai dengan garis wewenang (line autho $\neg$ rity) dan pelimpahan wewenang; seseorang hanya bertanggung jawab kepada orang yang melimpahkan wewenang tersebut

h. Principle of Departmentation (principle of devision of work-prinsip pembagian kerja). Menurut prinsip ini, pengelompokan tugas-tugas, pekerjaan-pekerjaan atau kegiatan-kegiatan yang sama ke dalam satu unit kerja (departemen) hendaknya didasarkan atas eratnya hubungan pekerjaan tersebut.

i. Principle of Personnel Placement (prinsip penempatan personalia). Menurut prinsip ini, hendaknya penempatan orang-orang pada setiap jabatan harus didasarkan atas kecakapan, keahlian dan keterampilannya (the right men, in the right job); mismanajemen penempatan harus dihindarkan. Efektivitas organisasi yang optimal memerlukan penempatan karyawan yang tepat. Untuk itu harus dilakukan seleksi yang objektif dan berpedoman atas job specification dari jabatan yang akan diisinya.

j. $\quad$ Principle of Scalar Chain (prinsip jenjang berangkai). Menurut prinsip ini, hendaknya saluran perintah/wewenang dari atas ke bawah harus merupakan mata rantai vertikal yang jelas dan tidak terputus-putus serta menempuh jarak terpendek. Sebaliknya pertanggungjawaban dari bawahan ke atasan juga melalui mata rantai vertikal, jelas dan menempuh jarak terpendeknya. Hal ini penting, karena dasar organisasi yang fundamental adalah rangkaian wewenang dari atas ke bawah; tindakan dumping hen $\neg$ daknya dihindarkan.

k. Principle of Efficiency (prinsip efisiensi). Menurut prinsip ini, suatu organisasi dalam mencapai tujuannya harus dapat mencapai hasil yang optimal dengan pengorbanan yang minimal.

l. Principle of Continuity (prinsip kesinambungan). Organisasi harus mengusahakan cara-cara untuk menjamin kelangsungan hidupnya.

m. Principle of Coordination (prinsip koordinasi). Prinsip ini merupakan tindak lanjut dari prinsip-prinsip organisasi lainnya. Koordinasi dimaksudkan untuk mensinkronkan dan mengintegrasikan segala tindakan, supaya terarah kepada sasaran yang ingin dicapai. Dalam konteks pendidikan Islam, prinsip-prinsip ini haruslah berlandaskan kepada landasan ajaran Islam itu sendiri. 


\section{Fungsi dan Tujuan Organisasi \\ a. Fungsi Organisasi.}

Sebenarnya dari definisi organisasi dapat dijabarkan menjadi fungsi organisasi. Purwanto menjabarkan fungsi organisasi sebagai berikut: 1) Organisasi dapat diartikan sebagai memberi struktur, terutama dalam penyusunan/penempatan personel, pekerjaan-pekerjaan, material, dan pikiran-pikiran di dalam struktur itu, 2) Organisasi dapat pula ditafsirkan sebagai menetapkan hubungan antara orang-orang, 3) Organisasi dapat juga diartikan semata-semata mengingat maksudnya, yakni sebagai alat untuk mempersatukan usaha-usaha untuk menyelesaikan pekerjaan-pekerjaan. ${ }^{13}$

Dengan demikian, kesimpulan yang dapat ditarik adalah bahwa organisasi dan pengorganisasian merupakan salah satu fungsi dari manajemen. Dari sisi wadah, organisasi memayungi manajemen yang berarti organisasi lebih luas daripada manajemen, tetapi dari sisi fungsi, organisasi (organizing) sebagai bagian dari fungsi manajemen, yang berarti organisasi lebih sempit daripada manajemen.

\section{b. Tujuan Organisasi}

Sedangkan tujuan dan manfaat organisasi menurut Usman, adalah: 1) mengatasi terbatasnya kemampuan, kemauan, dan sumber daya yang dimilikinya dalam mencapai tujuannya; 2) mencapai tujuan secara lebih efektif dan efisien karena dikerjakan bersama-sama; 3) wadah memanfaatkan sumber daya dan teknologi bersama-sama; 4) wadah mengembangkan potensi dan spesialisasi yang dimiliki seseorang; 4) wadah mendapatkan jabatan dan pembagian kerja; 5) wadah mengelola lingkungan bersama-sama; 6) wadah mencari keuntungan bersama-sama; 7) wadah menggunakan kekuasaan dan pengawasan; 8) wadah mendapatkan penghargaan; 9) wadah memenuhi kebutuhan manusia yang semakin banyak dan kompleks; 10) wadah menambah pergaulan; 11) wadah memanfaatkan waktu luang. ${ }^{14}$

Hendaklah suatu organisasi itu berjalan sesuai dengan perencanaan yang telah dibuat sebelumnya. Penyimpangan dari perencanaan tersebut akan menyebabkan organisasi menjadi berbelok dan sulit untuk mencapai tujuan yang ditetapkan. AD/ART suatu organisasi harus dijalankan secara konsekuen agar suatu organisasi mampu dinamakan organisasi yang efektif. Maka AD/ART juga merupakan elemen organisasi.

13 Ibid.

${ }^{14}$ Usman, Manajemen Pendidikan...,hlm. 140. 


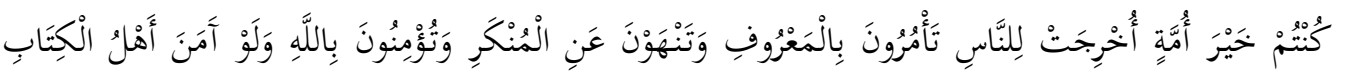

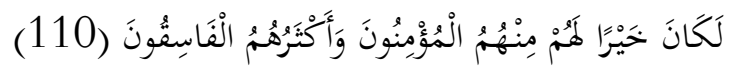

"Kamu adalah umat yang terbaik yang dilahirkan untuk manusia, menyuruh kepada yang ma'ruf, dan mencegah dari yang munkar, dan beriman kepada Allah. Sekiranya Ahli Kitab beriman, tentulah itu lebih baik bagi mereka, di antara mereka ada yang beriman, dan kebanyakan mereka adalah orangorang yang fasik". (Q.S.ali Imran: 110).

Khaira ummah di sini merupakan tafsir dari umat Islam akan menjadi umat yang terbaik apabila mengerjakan pilar-pilar agama Islam. Namun apabila ditarik dalam masalah organisasi yaitu mengandung pemahaman organisasi yang bermutu yang melaksanakan pilar-pilar mutu.

Organisasi dinyatakan efektif apabila tujuan anggota organisasi dan tujuan organisasi tercapai sesuai atau di atas target yang telah ditetapkan. Artinya baik pihak pelanggan internal maupun pelanggan eksternal organisasi merasa puas.

Usman menjelaskan beberapa indikator organisasi pendidikan bermutu dan efektif. Indikator tersebut antara lain sebagai berikut: 1) berfokus pada pelanggan, 2) berfokus pada upaya pencegahan masalah, 3) investasi kepada manusia dan menganggap manusia sebagai aset organisasi, 4) memiliki strategi untuk mencapai mutu, 5) memperlakukan keluhan sebagai umpan balik untuk memperbaiki diri (responsif), 6) memiliki kebijakan dalam perencanaan mutu, 7) mengupayakan proses perbaikan terus-menerus dengan melibatkan semua pihak terkait (partisipatif), 8) membentuk fasilitator yang bermutu (mau dan mampu memimpin proses perbaikan), 9) mendorong orang untuk berinovasi dan berkreasi, 10) memperjelas peranan dan tanggung jawab setiap orang, 11) memiliki strategi evaluasi yang objektif dan jelas, 12) memiliki rencana jangka panjang, 13) memiliki visi dan misi, 14) memandang mutu sebagai bagian dari kebudayaan, 15) meningkatkan mutu sebagai kewajiban, 16) terbuka dan bertanggung jawab..$^{15}$

\section{B. Simpulan}

Istilah organisasi mempunyai dua pengertian umum. Pertama organisasi diartikan sebagai suatu lembaga atau kelompok fungsional, misalnya: sebuah perusahaan, sebuah sekolah, sebuah perkumpulan, badan-badan pemerintahan. Kedua, merujuk pada proses pengorganisasian yaitu bagaimana pekerjaan diatur dan dialokasikan di

15 Usman, Manajemen Pendidikan...,hlm. 220.

$180 \mid$ JURNAL LISAN AL-HAL 
antara para anggota, sehingga tujuan organisasi itu dapat tercapai secara efektif. Sedangkan organisasi itu sendiri diartikan sebagai kumpulan orang dengan sistem kerja sama untuk mencapai tujuan bersama.

Terdapat dua kata bantu yang terdapat dalam al-Qur'an untuk mempelajari pengorganisasian ini. Kata tersebut adalah Shaff dan ummat. Untuk kata shaff menginspirasi konsep bahwa organisasi harus mempunyai anggota yang terdiri dari kumpulan orang-orang, berada dalam suatu wadah, terdapat keteraturan, mempunyai tujuan, juga mempunyai pemimpin, terjadi pendelegasian wewenang dan tanggung jawab serta ada niat melaksanakan tugas dengan ikhlas dan berjuang di jalan Allah. Agar terwujudnya suatu organisasi yang baik, efektif, efisien serta sesuai dengan kebutuhan, secara selektif harus didasarkan pada prinsip-prinsip organisasi yang berlandasan pada ajaran islam.

\section{DAFTAR PUSTAKA}

Ach., Mohyi, Teori dan Perilaku Organisasi, Malang : UMM Press, 1999. al-Baghawi, Abu Muhammad Hasan ibn Mas'ud, Mu'alim al Tanzil, Dar Tayyibah lin Nasr: Dalam Software Maktabah Samilah, 2005.

al-Bukhari, Abu Abdillah Muhammad ibn Isma'il, Shahih Bukhari juz 12, Mauqi'u al-Islam: dalam Software Maktabah Samilah, 2005.

al-Hajaj, Muslim, Shahih Muslim, juz 10, Mauqi'u al-Islam Dalam Software Maktabah Syamilah, 2005.

al-Hawary, Sayyid Mahmud, Idarah al-Asas wa al-Ushul al-Ilmiyah, Dar alKutub: Mesir, 1976.

al-Maraghi, Mustofa, Tafsir al-Maraghi, Kairo: Mustofa Babil Halabi, 1966.

al-Qurtubi, Samsyu al-Din, Jami' al-Bayan li al-Ahkam al-Qur'an, juz 1, Mauqi'u al-Tafasir: Dalam Software Maktabah Samilah, 2005.

al-Thabari, Ibn Jarir, Tafsir Jami' al Bayan fi ta'wil al-Qur'an, Mauqiu Majma' al Mulk: dalam Software Maktabah Samilah, 2005.

Al-Thabrani, Mu'jam al-Ausath, juz 2, Mauqi'u al-Islam: Dalam Software Maktabah Syamilah, 2005.

al-Thabrani, Mu'jam al-Kabir, juz 6, Mauqi'u al-Islam Dalam Software Maktabah Syamilah, 2005.

Amrullah, Haris Budiyono, Pengantar Manajemen, Yogyakarta: Graha Ilmu, 2004.

Fattah, Nanang, Landasan Manajemen Pendidikan, Bandung: PT Remaja Rosdakarya, 2004.

Hermawan, Daman, Cepi Triatna, "Organisasi Pendidikan" dalam Tim

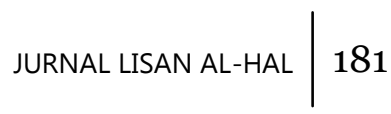


Dosen Administrasi Pendidikan UPI, Manajemen Pendidikan, Bandung: Alfabeta, 2009.

Majah, Ibn, Sunan Ibn Majah, juz 11, Mauqi'u al-Islam: Dalam Software Maktabah Syamilah, 2005.

Purwanto, Ngalim, Administrasi dan Supervisi Pendidikan, Bandung: PT Remaja Rosdakarya, 2007.

Sulistiyorini, Manajemen Pendidikan Islam, Surabaya: eLKAF, 2006.

Tanthowi, Jawahir, Unsur-Unsur Manajemen Menurut Ajaran Al-Qur'an, Jakarta: Pustaka al-Husna, 1983.

Usman, Husaini, Manajemen Pendidikan: Teori, Praktik dan Riset Pendidikan, Jakarta: Bumi Aksara, 2008.

Usman, Husaini, Manajemen Pendidikan: Teori, Praktik dan Riset Pendidikan, Jakarta: Bumi Aksara, 2006.

Wikipedia bahasa Indonesia, Ensiklopedia Bebas, Manajemen, diakses dari http://www.ririsatria.net/category/manajemen-organisasi, tanggal 25 Januari 2013

Winardi, Teori dan Pengorganisasian, Jakarta: Raja Grafindo Persada, 2009.

$182 \mid$ JURNAL LISAN AL-HAL 